\title{
Ideologia e Técnica em uma Definição Jurídica (a Definição Obertina de Feudo dos Glosadores a Cujas)
}

\section{Ideology and Technique in a Legal Definition (the Obertine Definition of Feudo from the Glossators to Cujas)}

\author{
Paolo Grossi ${ }^{1}$ \\ ${ }^{1}$ Universidade de Florença, Firenze, Itália
}

Resumo: $O$ texto examina o modo como os juristas, dos glosadores a Jacques Cujas, analisaram a definição de feudo na interpretação do direito comum à luz dos escritos de Oberto dell'Orto. Nessa perspectiva, o autor revê aspectos da situação real do feudatário como domínio útil, afirmando a inadequação técnica do usufruto para expressá-la, analisa a posterior caracterização dos feudos como quase-dominium, presente, sobretudo, em alguns juristas entre os séculos XVI e XVII.

Palavras-chave: Direito Medieval. Direito Comum. Glosadores. Feudos. Cujas.

\begin{abstract}
The paper examines the way jurists, since the glosses, until Jacques Cujas, analyzed the definition of feud within the interpretation of common law, in the light of the Oberto dell'Orto's writings. By this perspective, this author reviews aspects of the feudary real situation as an useful domain, grounding the usufruct's technical inadequacy to express it, as well as analyzing the fiefs' later characterization as quasi-dominium, found mainly in legal thought of sixteenth and seventeenth centuries' jurists.
\end{abstract}

Keywords: Medieval Law. Common Law. Glossaries. Fiefs. Cujas.

Recebido em: $10 / 02 / 2018$

Revisado em: 15/05/2018

Aprovado em: 10/06/2018 


\section{A Definição Obertina de Feudo na Interpretação do Direito Comum: a) a situação real do feudatário como domínio útil}

Na segunda das duas cartas que Oberto dell'Orto escreve ao filho Anselmo para instruí-lo sobre a difícil e, em Bolonha, desprestigiada matéria feudal que constitui o coração dos assim chamados "Libri feudorum", encontra-se uma famosa definição de feudo:

[...] est beneficium illud, quod ex benevolentia alicuius ita datur, ut proprietate quidem rei immobilis beneficiatae penes dantem remanente ususfructus illius rei ita ad accipientem transeat, ut ad eum heredesque suos masculos sive feminas, si de his nominatim dictum sit, in perpetuum pertineat, ob hoc, ut ille et sui heredes fideliter domino serviant, sive servitium illud nominatim, quale esse debeat, sit expressum sive indeterminate sit promissum ${ }^{1}$.

Oberto, um personagem de relevo na vida pública milanesa na metade do século $\mathrm{XII}^{2}$, é um operador do direito, mais avesso às avaliações grosseiramente substanciais imperantes nas cúrias feudais que aos sutis acenos teóricos emergentes entre os mais cultos dos Glosadores. Com a sua definição ele queria individualizar os elementos essenciais da relação feudal na sua singular mistura de aspectos refinadamente pessoais e patrimoniais; para esse último plano, a situação sobre o bem imóvel se dividia, restando ao senhor-concedente a propriedade formal e transferindo-se ao vassalo-concessionário o inteiro uti-frui (salvo alguns direitos senhoriais bem específicos). Tendo em vista que se trata de um gozo temporalmente ilimitado, é provável que, com usus-fructus, Oberto quisesse simplesmente dar a entender que o uti e o frui, isto é, o uso e

\footnotetext{
${ }^{1} \mathrm{O}$ texto aqui trazido é aquele da vulgata; a respeito da lectio antiqua, as divergências são de pura forma e não tocam a substância técnica da definição. (LEHMANN, 1896, p. 143; KARL LEHMANN, 1971). É evidente que, na acepção de Oberto, feudum e beneficium são sinônimos - como resulta claramente também do texto da primeira epístola obertina ao filho Anselmo (LEHMANN, 1896, p. 115) e como tais os interpretará toda a literatura posterior.

${ }^{2}$ Oberto dell'Orto foi, além do mais, um dos cônsules milaneses presentes na primeira Dieta de Roncaglia.
} 
o gozo do bem, passavam ao vassalo e aos seus herdeiros, e não que a esses tocasse o romanístico ius ususfructus, isto é, a servidão pessoal de usufruto, que uma tradição jamais negada limitava temporalmente à vida do concessionário.

Se nas Summae de Jacopo d'Ardizzone ${ }^{3}$ e de Jacopo Colombi ${ }^{4}$ e nas Epitome de Jean Blanc ${ }^{5}$ a definição obertina é recebida sem emendas interpretativas, já um personagem como Ostiense, nada sutil - na esteira do seu mestre Sinibaldo - com a nova categoria interpretativa do domínio, não hesitará - depois de ampla discussão - a qualificar como dominium utile a situação do feudatário ${ }^{6}$-, e, entre os séculos XII e XIII, o monarca feudistaraum Andrea de Isernia nos dirá que uma doutrina como essa já se tornou opinião comum: "hoc tenet omnes communiter"7; conclusão que, no final do século áureo dos comentaristas, foi enunciada justamente

3 "proprietate ... penes dantem remanente, ususfructus eius rei ... transeat ..." (ARIDIZZONE, 1584. T. X, Pars I, fol. 226 recto).

4 HUGOLINI [na realidade COLOMBI, Jacopo]. Summa super usibus feudorum. In: PALMERIO, J. B (Org.). B.I.M.AE., vol. II. Bononiae: Virano, 1892, I: "est feudum id beneficium quod a benevolentia alicuius ita traditur alicui ut, proprietate eius rei quidem immobiiis beneficiarie penes tradentem remanente, ususfructus eius rei ita ad accipientem transeat, ut...". O mesmo se pode dizer para Odofredo (cf. Summa ODOFREDI... in usus feudorum..., Compluti, 1584, cap. I - Quid sit feudum).

${ }^{5}$ BLANCHO, Ioanne. Epitome feudorum (in Tractatus illustrium iurisconsultorum, cit., T. X, Pars I, fol. 263 recto): "proprietate ... penes dantem remanente, ususfructus eius rei ita ad accipientem transeat ...". A Epítome blanchiana, muito menos conhecida do que as outras duas citadas anteriormente, deve remontar à metade do Dugento (cf. LASPEYRES, E. A. Über die Entstehung und älteste Bearbeitung der Libri Feudorum: Aalen, Scientia, 1969 (reimpressão anastática Ausg. Berlim, 1830), p. 81-82).

${ }^{6}$ HOSTIENSIS, Henrici de Segusio Cardinalis. Summa aurea. Venetiis: 1574, lib. III, de feudis, n. 1 (em que se reporta à definição obertina) e n. II (na qual se discute "quod ius acquiratur vasallo facta investitura" e onde, depois de uma série de argumentações que pareciam conduzir diretamente a uma solução negativa, conclui-se que "quicquid tarnen superius sit allegaturn, satis videtur dici posse quod habeat utile dominiurn"). Reticente sobre o problema da natureza jurídica da situação do vassalo é ao invés a definição de feudo contida na Lectura (cf. Henrici de Segusio Cardinalis HOSTIENSIS ..,, In tertium Decretalium librum commentaria ... Torino, Bottega d'Erasmo, 1965 (reimpressão anastástica, ed. Venetiis, 1581), De feudis, Rubrica, n. 5).

7 ISERNIENSIS, ANDREAE. In usus feudorum commentaria ...: Neapoli: 1571, de capitolis Corradi, v. Praeterea, Additio, n. 9. 
por Baldo $^{8}$ e que, na derradeira reflexão do direito comum clássico, no final do século $\mathrm{XV}$, sempre em referência ao texto obertino, é repetido por um jurista que até já começava a perceber a novidade dos tempos, Giason del Maino?.

Que a situação do vassalo não seja usufruto, mas domínio útil é verdade repetida por todos os clássicos da literatura sobre feudalismo, de Pseudo-Belleperche ${ }^{10}$ a Martino Sillimani ${ }^{11}$ a Jacopo Belvisi ${ }^{12}$, a Baldo ${ }^{13}$, a Jean Raynaud ${ }^{14}$, a Jacopo Alvarotti ${ }^{15}$, a Jacopino de San Giorgio ${ }^{16}$, a

${ }^{8}$ Que a situação do vassalo implique um usufruto "[est] falsum et ab omnibus reprobatur"
(BALDI perusini In usus feudorum comentaria: Lugduni, 1552, de capitolis Corradi, v. Praeterea, n. 2).

${ }^{9}$ Praeludia in opus feudorum, ao final de MAYNI, Iasonis ... In primam Codicis partem commentaria ..., Venetiis: 1598, n. 7 ("feudum est benivola concessio libera et perpetua rei immobilis vel aequipollentis cum translatione utilis dominii proprietate retenta sub fidelitate et exhibitione servitorum ... Dixi "cum traslatione utilis dominii”, quia in veritate dominium transit in vasallum seu feudatarium") e n. 18 ("feudum habet in aliquo similitudinem usufructui ... sed cave, quia in dicta diffinitione feudi ususfructus ponitur pro utili dominio, ut ibi dicunt Doctores").

${ }^{10}$ PERTICA, Petri Bella. Tractatus de de feudis. In: Tractatus illustrium iurisconsultorum, cit., T. X, Pars II, fol. 2 recto, n. 1.

${ }^{11}$ SILIMANIS, Martini de. Tractatus super usibus feudorum ... In: Tractatus illustrium iurisconsultorum, cit., T. X, Pars I, fol. 3 recto (sobre as relações entre o texto de Martino e aquele do Pseudo-Belleperche, cf. MEIJERS, E. M. L'université d'Orléans au XIII siécle, agora em Etudes d'histoire du droit, T. III, Le droit romain au Moyen Age, P. I, Leyde, Univ. Pers Leiden, 1959, p. 104-106).

12 BELVISO, Iacobi de. Apparatus ... super consuetudinibus usus feudorum. In: Commentarii in Authenticum et Consuetudines feudorum, Bolonha, Forni, 1971 (reimpressão anastática ed. Lugduni, 1511), fol. 80 verso.

${ }_{13}$ Baldi perusini In usus feudorum commentaria, cit., Proemium, n. 23 e também de capitulis Corradi, v. Praeterea, n. 2 ("Glossa disputatur utrum feudatarius habeat utile dominium et pro firma conclusione tenendum est quod sic").

${ }^{14}$ RAYNAUDI, Ioannis. Comprehensorium feudale, Lugduni, 1561, in v. Imperialem, nn. 7 e 8.

${ }^{15}$ ALVAROTTI, Iacobi. ... Lectura in iusus ..., Francofurti ad Moenum, 1570, Prooemium, n. 18.

${ }^{16}$ GEORGIO, Iacobi de S. Tractatus. In: Tractatus illustrium iurisconsultorum, cit., T. X. Pars I, fol. 188 verso. 
Claude de Seyssel ${ }^{17}$, a Francesco Corti o jovem ${ }^{18}$, até chegar intacta na página de um jurista como Zasius ${ }^{19}$, que está dividido entre passado e futuro no seu fertilíssimo observatório renano dos primeiros anos do século $\mathrm{XVI}^{20}$; e frequentemente com esclarecimentos que sublinham como, com o termo ususfructus, Oberto tivesse intencionado destacar um conteúdo econômico e já não uma figura técnico-jurídica.

O mais explícito nos parece Jacopo Belvisi, e é oportuno ponderar as suas palavras: depois de ter se referido a uma primeira definição não satisfatória de feudo ${ }^{21}$, contrapõe-na a uma mais complexa e articulada, que é a seguinte:

Feudum est concessio rei facta cum traditione utilis dominii ad utendum et fruendum cum exhibitione alicuius honesti servitii. Utendum et fruendum: ideo dicit, quia feudatarius habet usum et usumfructum $^{22}$.

Nota-se como o jurista tem o cuidado de precisar que o uti e o frui, o uti-frui, são o conteúdo econômico do domínio útil; o gozo do bem que, em certas situações e condições, pode se tornar esse mesmo, pela própria força, uma propriedade sobre o bem ${ }^{23}$. A concessão feudal não é nada mais que uma concessão ad utendum et fruendum, a qual, para

${ }^{17}$ SEYSSELI, Claudi ... Speculum feudorum ..., Basileae: 1566, p. 65 e 68-69.

18 CURTII, Francischini junioris ... Tractatus feudorum. In: Tractatus illustrium iurisconsultorum, cit., T. X, Pars II, quaestio sexta, cap. VII, nn. 1 e 2.

19 ZASII, Udalrici ... In usus feudorum epitome. In: U. Z. Operum tomus tertius ..., Lugduni: 1550, col. 268, n. 24.

${ }^{20}$ Sobra a complexa e ambiforme personalidade zasiana, ver o que já se teve ocasião de anotar, justamente sobre o tema do domínio útil, em um artigo precedente. Cf. Quaderni fiorentini per la storia del pensiero giuridico moderno, 14 (1985).

21 "Feudum est concessio rei pro homagio facta" (BELVISO, Iacobi de. Apparatus, fol. 80 verso).

${ }^{22}$ BELVISI, Iacopo. Apparatus, loc. ult. cit.

${ }^{23}$ Sobre como emerge à comum consciência jurídica essa ideia profunda do domínio útil e como essa se torne também uma arquitetura doutrinal, permitimo-nos reenviar o leitor a algumas nossas recentes reflexões: GROSSI, Paolo. La proprietà e le proprietà nell'officina dello storico. In: Quaderni fiorentini per la storia del pensiero giuridico moderno, 17 (1988). 
a verificação daquelas determinadas condições, tem a vitalidade de se transformar em dominium utile. E Jacopo reforça, para questionar a ideia falaciosa de uma referência mental à servidão pessoal de usufruto que a equivocidade do termo pudesse gerar: fala-se de usufructus, porque o feudatário tem a inteireza do gozo da coisa.

Que usufructus seja aqui uma noção juridicamente inócua, quase um sinônimo de commodum, o feudista o demonstra pouco mais adiante, quando, perguntando-se o que é o beneficum e replicando com a tradicional resposta de que esse consiste em uma "benivola actio tribuens gaudium capienti" ${ }^{24}$, esclarece de tal modo a palavra gaudim: “[...] quod qui accipit feudum percipit usumfructum et commodum, quod est gaudium, quia gaudium est et solatium capere fructum"25.

Em suma, usufructus vale gaudium et solatium, consiste em um capere fructus. É apenas o conteúdo econômico, como acima se dizia, do domínio útil. Como afirma o próprio Jacopo Belvisi e repetem muitos ${ }^{26}$, a situação do feudatário é "dominium utile ad utendum fruendum", é "commoditas et usufructus, immo utile dominium"27, em que a construção técnica que emerge a nível do direito é domínio útil - construção técnica da qual decorrem múltiplas consequências técnico-jurídicas - e em que o assim chamado "usufruto" é apenas o recipiente factual daquela figura, a única que seja juridicamente relevante.

${ }^{24}$ Tradicional, porque aparece já na carta de Oberto dell'Orto, que a havia tomado completamente do "De beneficiis" de Seneca (lib. I, cap. 6).

${ }^{25}$ BELVISI, Iacopo. Apparatus, cit., loc. ult. cit.

${ }^{26}$ [Pseudo] BELLEPERCHE, Pierre de. Tractatus de feudis, cit., fol. 2 recte ("concessio rei facta alicui cum translatione utilis dominii ad habendum et fruendum cum exhibitione alicuius servitii honesti"), com fórmula que foi transcrita por SILLIMANI, Martino. Tractatus super usibus feudorum, cit., fol. 3 recto; RAYNAUD, Jean. Comprehensorium feudale, cit., v. Imperialem, n. 7 ("feudum est benivola libera et perpetua concessio rei immobilis vel solo cohaerentis, aut inter immobilia computatae, ad utendum fruendum cum translatione utilis dominii, proprietate retenta, sub fidelitate et exhibitione servitii'). ${ }^{27}$ ISERNIA, Andrea di. In usus feudorum commentaria, cit., Ex quibus causis feudum amittatur, v. Huius autem generis, n. 6 ("proprietas rei immobilis ... remaneat apud dominum dantem, sed commoditas et ususfructus, immo utile dominium, sit vasalli et suorum haeredum"). 


\section{A Definição Obertina de Feudo na Interpretação do Direito Comum: b) sobre a inadequação técnica do usufruto para exprimir a situação real do feudatário}

A intepretação da expressão obertina é, então, sem meios termos, que "in dicta diffinitione feudi ususfructus ponitur pro utili domínio"28 e que nessa "usufructus [...] non videtur congruus terminus"29, "non ponitur proprie" ${ }^{30}$. Claude de Seyssel, com a desenvoltura que nasce dos quase três séculos e meio que o separam de Oberto, liquida o problema em juízo depreciativo: “[...] patet quod ista fuit rustica descriptio, non elegans diffinitio"31; e percebe pelo menos, com a ênfase no caráter não dogmático da definição, que pretendia ser o instrumento de compreensão e de simplificação da estrutura substancial de um caso complexo como o feudo, confeccionado por um operador do direito para um discente, e reduzido a um resultado de cisão da proprietas do uti-frui. Se Giason del Maino tenta atenuar as responsabilidades técnicas de Oberto admitindo que "feudum habet in aliquo similitudinem usufructui" 32 e que se trata, portanto, de erros, sim, mas escusáveis, os demais insistem sobre a magina differentia que intercorre entre a figura do vassalo e do usufrutuário ${ }^{33}$.

Como se acredita ter demonstrado em uma pesquisa recentíssima ${ }^{34}$, vassalo e usufrutuário pertencem a planetas jurídicos - mais que diversos - opostos nas suas características essenciais: o primeiro, como dominus utilis, àquele do dominium, que é sempre, também no caso do domínio útil, aquele do pertencimento da res, mesmo que de uma dimensão só da

\footnotetext{
${ }^{28}$ MAINO, Giason del. Praeludia in opus feudorum, cit., n. 18.

${ }^{29}$ SEYSSEL, Claude de. Speculum feudorum, cit., p. 37.

${ }^{30}$ CORTI, Francesco o jovem. Tractatus feudorum, cit., q. VI, cap. VII, n. 6.

${ }^{31}$ SEYSSEL, Claude de. Speculum feudorum, cit., p. 68-69.

${ }^{32}$ MAINO, Giason del. op. ult. cit.

${ }^{33}$ A frase é de CORTI, Francesco o jovem. Tractatus feudorum, cit., q. VI, cap. VII, n. 6; "Multum differt istud ius feudi ab usufructu", diz SEYSSEL, Claude de. Speculum feudorum, cit., p. 37.

${ }^{34}$ GROSSI, Paolo. 'Dominia'e 'servitutes'- Invenzioni sistematiche del diritto comune in tema di servitù, in Quaderni fiorentini per la storia del pensiero giuridico moderno, 18 (1989).
} 
coisa, a utilitas; que é, em primeiro lugar, autonomia de poderes reais sobre a coisa ${ }^{35}$, tanto que ele poderá, legitimamente, no libelo propositivo de uma lide que tenha por objeto a coisa, "dicere rem ad se iure dominii pertinere"36; o segundo, como titular de um direito real limitado, aquele da servidão - em particular, das servidões pessoais - que é estranho ao pertencimento da coisa e que representa o mundo de criaturas jurídicas não autônomas carentes da solidez de um dominium para compensar a própria debilitas ${ }^{37}$.

E será justamente essa diversidade - aliás, para dizer melhor, essa oposição lógica - a ser chamada pelos Doutores para assinalar a perigosa equivocidade do termo ususfructus colocado por Oberto bem no meio da sua definição. Com um extraordinário rigor técnico e com uma também extraordinária capacidade perceptiva, Zasius, homem igualmente partícipe de dois mundos culturais, parece exprimir melhor que qualquer outro, no início do século XVI, o significado da complexa elaboração dos séculos precedentes:

Vasallus ex feudi concessione utile dominium consequitur ...nec obstat quod in diffinitione feudi dicitur 'ad utendum et fruendum' quasi vasallus usufructuarius sit, quia huiusmodi verba fruendi facultatem iure proprio, non iure servitutis personalis important ...Veritas tamen est vasallum feudo uti et frui tanquam utili dominio posse. Siquidem quando verba utendi et fruendi in principalis dispositionis consequentiam ponuntur, proprietatem significant. Consequenter praedictis inferas quod vasallus ratione utilis dominii rei ven- dicationem habet, ut a quocumque possessore vendicet ${ }^{38}$.

\footnotetext{
${ }^{35}$ É o que se tenta demonstrar em diversas pesquisas precedentes, todas resumidas em GROSSI, Paolo. La proprietà e le proprietà nell'officina dello storico, cit., ao qual se remete para uma adequada documentação.

${ }^{36}$ BALDO. In usus feudorum commentaria, cit., de capitulis Corradi, v. Praeterea, n. 2.

${ }^{37}$ GROSSI, Paolo. 'Dominia' e 'servitutes', cit. passim.

${ }^{38}$ ZASIUS. In usus feudorum epitome, cit., col. 268, nn. 34, 35, 36, 37.
} 
O objeto de uma relação de locação e o conteúdo da faculdade concedida pelo locador ao condutor podem consistir em uti-frui; este pode formar o objeto de uma constituição de usufruto e o conteúdo do poder do usufrutuário sobre o bem; mas, em uma civilização jurídica como aquela medieval, toda propensa a valorizar a efetividade dos dados econômicos, pode significar alguma coisa além de qualitativamente diverso e superior: se trata-se de gozo imediato, autônomo, efetivo sobre a coisa, esse fato econômico tem uma validade tão intensa a ponto de se transformar e se elevar em dominium. Assim é para o enfiteuta, assim para o superficiário, assim para o condutor a longo prazo, assim também para o vassalo. A sua situação é aquela de uma facultas iure próprio, não de um ius servitutis personalis. Ele é - na sua ordem - um dos proprietários da coisa, em equivalência ao senhor, ao concedente; um é dominus utilis, e o outro dominus directus. E lhe caberá, como instrumento de tutela processual, a ação reivindicatória.

Os Doutores perceberão minuciosamente as numerosas differentiae, que na situação jurídica do vassalo derivam do seu ser dominus e não usufructuarius: cabe-lhe, como há pouco se dizia, a reivindicatio e não a simples ação confessória prevista para as servidões (e, portanto, para o usufruto ${ }^{39}$; torna seus os frutos pendentes, enquanto o usufrutuário os conquista unicamente com a percepção $0^{40}$; pode constituir direitos reais limitados sobre o fundo, poder que é negado ao usufrutuário ${ }^{41}$.

\footnotetext{
39 "[feudatarius] si non habet utile dominium, non haberet reivendicationem sed confessoriam, quae pro servitute ususfructus datur, quod falsum et ab omnibus reprobatus". BALDO. In usus feudorum commentaria, cit., de capitulis Corradi, v. Praeterea, n. 2. 40 "Magna enim est differentia inter vasallum et usufructuarium, quia vasallus habet utile dominium rei infeudatae et per consequens fructuum pendentium, usufructuarius vero perceptorum fructuum tantum habet dominium" Corti, Francesco o jovem. Tractatus feudorum, cit., q. VI, cap. VII, n. 6.

${ }^{41}$ GROSSI, Paolo. "Dominia” e "servitutes", cit., passim.
} 


\section{A Reflexão sobre a Situação Real do Feudatário no Debate Quinhentista: o discurso inaugural de Charles Dumoulin}

Os Doutores do direito comum clássico - civilistas, canonistas, feudistas que fossem - em uma grande linha contínua que vai do Ostiense ao citado Zasius, movem-se, na sua interpretatio da definição obertina, sobre um plano de construção refinadamente técnica. Têm entre as mãos, aplicado em todo lugar na experiência cotidiana, a sua moeda de troca que é o domínio útil, um uti-frui que se faz dominium; constatam que a situação real do feudatário consiste ela também em um gozo do bem com características autênticas de domínio; com dedução quase silogística, leem em chave jurídica como domínio útil a referência obertina ao usufruto entendido como mera referência econômica. Os Doutores verificam, em outras palavras, a definição na práxis feudal que os circunda e dão uma leitura dela que se situa sobre o plano da pura consciência jurídica.

Indo mais além, naquele quadrivium complicado que é o século XVI, prossegue sem problemas uma tendência do gênero naqueles filões teórico-práticos que se colocam como repetidores da configuração tradicional, mas não nos interessa examiná- $\operatorname{los}^{42}$. Interessa-nos, ao invés, dar uma olhada naquele mundo de homines novi, do qual o novo século é repleto e que constituem o tecido fértil da ciência jurídica do século XVI; tecido no qual o velho e o novo, com medida variada a depender do personagem, misturam-se, mas em que também o velho assume formas e substâncias renovadas para o renovado olhar metodológico com o qual os juristas neotéricos o veem. Um verdadeiro quadrivium repleto de ideias, complexo, pelo qual convém sem hesitações encaminharmo-nos; atribuindo uma primeiro posição, de fato destacada, à voz de Charles Dumoulin.

Cabe a ele esse papel inaugural talvez também porque o testemunho, ao qual se faz referência, remonta com certeza aos anos

\footnotetext{
${ }^{42}$ Para um exemplo, ver o texto de resumo de um jurista de área germânica, o Rosenthal, que escreve no final do século XVI: ROSENTALL, Henrico A. Tractatus et synopsis totius iuris feudalis. Colonia: 1610 (a primeira redação parece ser de 1588).
} 
que vão de 1535 a $1539^{43}$; mas o ponto não é de simples cronologia. Dumoulin está verdadeiramente entre velho e novo, tanto que poderia não equivocadamente, ainda que ingenuamente - trazer dificuldades o questionamento sobre se ele deva ser considerado o último entre os velhos ou o primeiro entre os novos. Diferentemente do ambíguo Zasius, que no seu apêndice aos Usus revela uma prevalência de elementos tradicionais, Dumoulin assinala com vivacidade o próprio pertencimento ao novo hemisfério cultural. A face tradicionalista desse extraordinário homem bifronte está, como se demonstrou em outra pesquisa, na aceitação incondicionada do domínio útil como categoria interpretativa da realidade jurídica; em Dumoulin, isso, que já ao redor dele começa a ser seriamente discutido, se não demolido e depreciado ${ }^{44}$, ;e subitamente acolhido; talvez, seja o registro - por parte de um personagem imerso na prática de uma realidade quotidiana francesa na qual o domínio útil a tornava o padrão, mas o fato é: a invenção de acursianos e bartolistas circula sem ser incomodada nas suas páginas.

A referência ao observatório particular do jurisconsulto parisiense nos introduz, porém, subitamente na sua muito intensa e caracterizante dimensão "moderna". Inicialmente, um apontamento: ele não comenta, como Zasius e como tantos juristas humanistas depois dele, os Libri feudorum; ao invés, olha-os bem. As assim chamadas consuetudines feudorum são aos seus olhos apenas "opinio cuiusdam Oberti", um jurista "mere privatus", e, portanto, "scriptura privata et nullius auctoritatis" "45, que não apenas não têm alguma vis $\operatorname{legis}^{46}$, mas nem

${ }^{43}$ É o seu monumental comentário à coutume de Paris, iniciado em 1535 e realizado no que se refere ao primeiro título "de fiefs" - em 1539 (cf. THIREAU, J. -L. Charles Du Moulin (1500-1566) - Étude sur les sources, la méthode, les idées politiques et économiques d'un juriste de la Renaissance. Genève: Droz, 1980, p. 31).

${ }^{44}$ Cf. mais abaixo, p. 193.

${ }^{45}$ DUMOULIN, Charles. In duos priores títulos Consuetudinis Parisiensis Commentarii. In: MOLINAEI, Caroli ... Opera quae extant omnia. Parisiis, 1658, T. I, col. 40, n. 100. 46 "succedit famigerata ista quaestio, et istituto nostro satis necessária utrum liber ille feudorum habeat vim et authoritatem legis, quod vulgo dicunt, an sit authenticus. Et omissis somniis fere omnium hac in re scribentium, quod liber ille sit decima collatio, quasi ab Imperatore aliquo fuerit approbatus, et novem novellarum Iustiniani collectionibus ad 
mesmo a denominação com autoridade de norma consuetudinária ${ }^{47}$, e que é arbitrário e falacioso considerar parte do Corpus iuris $^{48}$, já que teria o mesmo título da coutume d'Orléans ou qualquer outra coutume francesa ${ }^{49}$; a favor dessas últimas contaria ao menos a difusão da ideia de que não se trata de usos de fatos recolhidos por um privado, mas de costumes sancionados pelo poder régio que possuem caráter extremamente normativo. Dumoulin se vangloria, de fato, de um lado, de ter desmontado o castelo de cartas que conferia sutilmente eficácia normativa a um uso local na região da Insubria ${ }^{50}$, a uma fonte estranha à tradição da pátria consuetudinária francesa, e, de outro, de ser o primeiro comentador da Coutume de Paris, fonte - esta sim - expressão autêntica do espírito nacional, "caput omnium huius Regni Franciae et totius etiam Belgicae Galliae consuetudinum" ${ }^{51}$, que tinha recebido em 1510 a sua definitiva e oficial redação e à qual ele dedica - seja mesmo em várias retomadas - mais de vinte anos de minuciosa reflexão.

É essa uma abordagem de extrema relevância: o "bartolista" Dumoulin não hesita em profanar uma fonte que o transcorrer dos séculos havia camuflado de autoridade, que gerações de Mestres haviam se esforçado para explicar em suas cátedras e que todo causídico havia manejado com respeito e aproveitamento na práxis forense quotidiana; e o faz com aquela violência verbal que é um traço distintivo do costume humanístico nos juízos sobre o passado recente. Sob esse

decimam complendam annexus, quod ridiculum et ad placitum confictum puto: in hac sum nova opinione ..." (loc. ult. cit.).

47 "et sic tanquam opinio vel scriptura unius privati, nullius est auctoritatis, nec meretur nuncupari consuetudo, sed opinio et testificatio cuiusdem Oberti de consuetudinibus et legibus imperialibus super feudis" (loc. ult. cit.).

48 “consequitur falsum esse quod vulgo quidam opinantur ... librum feudorum esse de corpore iuris civilis". E ainda: "[Bartolus] vocat dictum librum feudorum decimam collationem, quod non minus est ineptum et ridiculum quam falsum" (ibidem, coll. 12-13, n. 24). E ainda: ibidem, col. 40, n. 100, o texto eloquentíssimo citado na nota 46, em que Dumoulin se orgulha da sua nova opinio.

${ }^{49}$ Loc. ult. cit.

50 "ille textos non sunt ius scriptum sed privata recitativo quarundam consuetudinum localiu Insubriae circa feuda" (ibidem, col. 1503, n. 16).

${ }^{51}$ Ibidem, col. 5, n. 2. 
perfil, Dumoulin se insere perfeitamente na revisão e historicização das fontes feudais levada adiante por vários dos juristas $\operatorname{cultos}^{52}$. E se deixa voluntariamente absorver pelo exame renovado das fontes nacionais francesas, já digníssimas aos seus olhos "modernos" de merecer a atenção do cientista mais preparado.

O seu microcosmo de jurista é o Reino da França, e o seu ius commune é o complexo das coutumes vigentes naquele território ${ }^{53}$, como foi assinalado pelos idiotismos franceses correntes na prática, que retalham sempre com mais frequência o seu latim erudito. Dumoulin demonstra, em suma, também sob esse perfil, pertencer àquilo que Donald Kelley chamou de modo feliz de "vernacular humanism" 54 , querendo destacar a profunda atração que pelo particular e pelo local sentem a maior parte dos juristas humanistas; uma tensão historicista, que pretende ser valorização do particular, sua elevação a macrocosmo e que, para o histórico do direito, significa, portanto, ruptura com uma tradição que tinha visto o jurista mover-se "in orbem terrarum" 55 .

Costume, linguagem práticas religiosas, regras jurídicas particulares, advertidas como manifestações de uma realidade nacional,

${ }^{52}$ Leem-se as anotações de KELLEY, D. R. De origine feudorum: The Beginnings of an historical Problem (1964), agora em KELLEY, D. R. History, Law and the Human Sciences - Medieval and Renaissance Perspectives, London, Variorum Reprints, 1984; e Id., Foundations of Moderns Historical Scholarship - Language, Law and History in the French Renaissance. New York: Columbia Unv. Press, 1970 (sobretudo os capítulos VI e VII).

${ }^{53}$ Cf. P. PETOT, Le droit commun en France selon les coutumiers, in Rev. Hist. de Dr. Fr. et Etr., s. IV, XXXVIII (1960); V. PIANO MORTARI, Diritto romano e diritto nazionale in Francia nel secolo XVI, Milano, Giuffrè, 1962, sobretudo, p. 61 ss. A voz de Dumoulin foi expressada com limpidez em: In duos priores títulos Consuetudinis Parisiensis commentarii, cit., col. 44, n. 106 ss.

${ }^{54}$ A afirmação foi feita a propósito de Louis Charondas Le Caron, mas é suscetível de ser generalizada por diversos filões do humanismo jurídico francês. Cf. KELLEY, D. R. Louis Le Caron philosophe (1976), agora in KELLEY. History, Law and Human Sciences, cit., p. 37.

${ }^{55}$ Sobre isso insistiu, com razão, MORTARI, Piano. Diritto romano e diritto nazionale in Francia nel secolo XVI, cit., passim, e Il diritto positivo in Francia nell'Epoca del mos gallicus, in MORTARI, V. Piano. Diritto logica método nel secolo XVI. Napoli: Jovene, 1978. 
são submetidos a um salto de plano: o jovem jurista francês, galicano e nacionalista, em plena sintonia com os projetos políticos da Monarquia, sente-se e é personagem substancialmente novo, isto é, novo pela carga psicológica e base cultural. O "galicano" Dumoulin, mesmo com todo o patrimônio do seu saber bartolista, sente-se confortável em respirar o ar do próprio tempo, possui aquela nova carga e aquela nova base.

Dir-se-á, então: o que tem a ver Molinaeus com o nosso problema? O que tem a ver se retira da sua mesa de trabalho os Libri feudorum? É preciso ser claro: não os elimina de fato. Aquilo que o motiva é ridicularizar e destruir a inserção augusta no Corpus iuris e a autoridade de fonte normativa, mas os terá constantemente presentes também se em posição marcadamente dialética. A definição obertina lhe é bem conhecida, mas desprovida de força jurídica, permanece por ele colocada no ventre daquele longínquo, oh quanto longínquo, século XII e submetida a uma reducionista avaliação historicista: então o domínio útil era situação tão intrinsecamente frágil que Oberto o qualificou como usufruto $^{56}$. É uma definição de feudo que não lhe agrada e à qual prefere ante aquela do jurista de Avignon do início do século XV Jean Raynaud $^{57}$, mas com a qual se confronta; como ama sempre confrontar-se dialeticamente com todo o patrimônio de noções e construções dos Libri.

Aquilo que cumpre destacar é, em primeiro lugar, que também Dumoulin lê usufruto, mas traduz juridicamente domínio útil; em segundo lugar, que torna sua uma definição de feudo - aquela raynaudiana - a qual fixa no seu centro, como característica natural da concessão feudal, uma translatio utilis dominii ${ }^{58}$. O observador concreto e atento da

56 "certum est autem rei beneficiariae in feudum traditae non transire dominium directum in clientem seu vasallum, sed remanere proprietatem penes dominum et solum transferri in clientulum quoddam utile dominium, quod est adeo debile, ut in usibus feudorum reputatur ususfructus" (In duos priores títulos Consuetudinis Parisiensis commentarii, cit., col. 7, n. 9).

${ }^{57}$ Foi citada mais acima, nas notas 14 e 26. A adesão de Dumoulin está em: In duos priores títulos Consuetudinis Parisiensis commentarii, cit., col. 46, n. 114.

58 Repete-se aqui por comodidade do leitor a definição de Jean Raynaud: "Feudum est benivola libera et perpetua concessio rei immobilis vel solo cohaerentis, aut inter immboilia computatae, ad utendum fruendum cum translatione utilis dominii, proprietate retenta sub fidelitate et exhibitione servitii" (ver a citação mais acima, na nota 26). 
vida social francesa do século XVI, o homem imerso até o pescoço na prática forense, não podia não chegar a essa firme conclusão: em torno a si havia um enxame de entidades feudais de conteúdo já distintamente patrimonial, em que o velho concessionário do uti-frui tinha visto crescer a tal dimensão a gama dos seus poderes a ponto de não ser apenas um seguro partícipe da titularidade do bem, mas o substancial propriétaire diante de um dominus directus já similar ao titular de um ius in re aliena na falta dos seus direitos honoríficos e senhoriais.

Dumoulin olha para a práxis nessa sua presente deformação sociojurídica do instituto feudal e longe de demonstrar a desdenhosa repugnância do abstrato homem de ciência, leva isso em conta realisticamente, contrapondo com o manifesto orgulho nacionalista o direito vulgar francês àquele imponente da tradição romanística:

Secundurn cornmunern nostrurn rnodurn loquendi aliter quarn in iure scripto accipimus istud verburn proprietas, quia de iure proprietas strictius et dorniniurn latius accipitur ... appellatione enirn dorninii venit ornne dorniniurn, sive directum sive utile sive feudale sive ernphyteuticurn ve1 superficiariurn et etiarn dominiurn iuriurn ...,sed proprietas non capitur nisi pro ipso directo dominio ... Sed apud nos est econverso, quia dominus directus non dicitur proprietarius nec habere proprietatern soli, sed solurn dorniniurn suurn superius, vassallus autem, censuarius ve1 ernphyteuta dicitur habere verurn dorninium et proprietatern ipsius rei: et hunc solum proprie- tariurn vocarnus ... In tota patria consuetudinaria vassalli et sirniles domini utiies, domini et proprietarii rerurn vocantur ${ }^{59}$.

Na França do século XVI, o vassalo se coloca já como painel divisório entre o bem e o senhor-concedente; sob o perfil dos poderes é a ele que cabe a imediata dispositio, enquanto se torna remota, mediata a relação potestativa do outro. Dumoulin não se escandaliza e percebe essa

\footnotetext{
${ }^{59} \mathrm{O}$ texto nasce como glosa ao termo "proprietaires" contido na Coutume partidária (In duos priores titulos Consuetudinis Parisiensis commentarii, cit., col. 1181, nn. 1 e 2). Outro texto interessante, porque insiste sobre um uti-frui que se faz dominium, é Ibidem, col. 187, n. 9, em que se fala do "dominus utilis, quem Gallici vulgo proprietarium vocant".
} 
experiência típica do costume jurídico francês como um passo inicial mas na continuidade - a respeito da tradição do direito comum, que não hesitara em conclamar o caráter autenticamente dominador do domínio útil e em separar conceitualmente o planeta das servidões daquele da pertença, e então do próprio domínio útil ${ }^{60}$. Na esteira de Baldo, ele se satisfaz em repetir que "dominium utile non est servitus" opinião comum dos Doutores é seguro em considerar criações jurídicas incompatíveis entre si feudo e usufruto.

Um caso prático sobre o qual o nosso jurista se debruça e se delonga com uma análise abundantíssima e merecedora de ser aqui destacada pela sua pontualidade: pode o usufrutuário de um feudo realizar atos de caráter estritamente feudal, isto é, inerentes à qualidade feudal do sujeito e do bem? A pergunta é legítima, porque o usufrutuário tem nas suas mãos aquele fato relevante constituído pela inteireza do gozo do bem, mas a resposta é sem mais delongas negativa, e encontra a própria motivação na conclusão de que

[...] sunt actos exiguibiles per solos dominos, tam ex parte patroni quam ex parte vasalli, et omnino incompatibiles vel inexiquibiles per símplices usufructuarios sive ex parte patroni sive ex parte vasalli"62; de fato "qualitas feudalis est realis et perpetua, sed ususfructus est contradictorie oppositus, utpote personalis et temporalis ${ }^{63}$.

A respeito da coisa, o usufrutuário, mesmo com toda a sua própria quantidade de gozo é um estranho ${ }^{64}$, diferentemente do dominus, de cada dominus, com o qual está inseparavelmente envolvido. O usufrutuário não possui jamais a capacidade de incidir no território a ele vedado pela pertença jurídica.

\footnotetext{
${ }^{60}$ Segue-se o fio desse episódio conceitual em uma recente pesquisa: "Dominia" $e$ "servitutes" - Iinvenzioni sistematiche del diritto comune in tema di servitù, cit.

${ }^{61}$ In duos priores títulos Consuetudinis parisienses commentarii, cit., col. 186, n. 7.

${ }^{62}$ Ibidem, col. 54, n. 13.

${ }^{63}$ Ibidem, col. 54, n. 12.

${ }^{64}$ Ibidem, col. 54, n. 10 ("res ipsa dicitur respectu fructuarii in totum aliena").
} 
Então, inadmissibilidade de conceber a relação feudal como translação de usufruto, e adesão à opinião comum que distinguia uma translação de domínio útil (ainda que se, pouco a pouco, esse domínio, do século IV em diante, tenha feito a parte do leão). Obviamente, como se dizia no início, plena aceitação da doutrina da propriedade divisa e da categoria do domínio útil.

De início se dizia que Dumoulin não discute isso que o mundo científico francês ao invés começou a discutir seriamente e asperamente. Será aqui interessante acrescentar que o nosso juristra não ignora aquelas discussões, ao invés, as pressupõe, mas prescinde delas; e o faz por uma visão realística da ordem jurídica. Lição de realismo para todos aqueles que haviam rasgado suas vestes - por exemplo, Jean Feu diante da constatação de que o domínio útil ou direto não é mencionado no Corpus iuris. Dumoulin o admite, é conscientíssimo disso; admite que a categoria é cientificamente nova e que é criação dos Mestres de direito comum, mas não visualiza o fato como uma vergonha. Aliás, é um mérito, e não pequeno, daquela iurisprudentia. A qual deu voz e corpo a traços conceituais potencialmente já inclusos, ainda que não expressos, no Corpus Justiniano, oferecendo aos juristas um precioso instrumento sistematizador; um instrumento, que é válido de per se, ainda que sem chegar a questionar os pressupostos das ações direta e útil, já que é a própria vida jurídica a nutrir em si precisamente as figuras do proprietário útil e do direto ${ }^{65}$.

Há ainda, talvez, nesse discurso corajoso e inescrupuloso, também a tentativa de salvar os intérpretes medievais compreendendo o valor evolutivo da sua interpretatio (aquilo que o humanismo não chegará nunca a fazer), a intermediação que esses tinham pretendido realizar entre lei velha e fatos socioeconômicos novos; mas há certamente uma avaliação

${ }^{65}$ Para a posição de Dumoulin em tema de domínio útil não podem deixar de citar, à análise feita na pesquisa contida nesse mesmo "Quaderno": La categoria del dominio utile e gli "homines novi" del quadrívio cinquecentesco. Vê-se, sobretudo, o texto citado na página 235, em que o jurista partidário defende a invenção dos Mestres do direito comum, porque expressiva da verdadeira mens iuris, metodologicamente necessária, válida "etiam de per se" sem fazer recurso a elucubrações complicadas sobre ações diretas e úteis. 
realista e de efeito da scientia iuris: o domínio útil, antes que nas páginas dos Doutores, é instituto da vida de cada dia, é ontologicamente presente, quer se queira ou não. É muito mais inteligente reconhecer esse fato e ordená-lo, compondo harmonicamente reflexão científica e instâncias da práxis, em vez de rejeitá-lo em nome de uma pureza metodológica absolutamente abstrata. Dumoulin, bem plantado na terra da sua França do século XVI, não se presta a essa mesma estéril operação.

\section{O Feudo como Quasi-Dominium: Le Douaren e Baron}

A situação do feudatário não consiste em um usufruto, mas em uma substancial propriedade, e faz bem o droit coutumier a qualificá-lo proprietaire: é essa a abordagem de Dumoulin, uma abordagem que se define realista.

Mas não todos os neotéricos têm a ousadia do grande operador do direito parisiense. Dir-se-ia, ao invés, que o embaraço serpenteia: se, de um lado, é insustentável a sua redução a usufruto, de outra, deve-se também reconhecer a subversão completa das velhas sistematizações romanistas admitindo o vassalo à proprietas. Uma solução mediana, que supere a absurda interpretação literal da definição obertina e não desconheça a intensa posição real do vassalo, parece a qualquer um uma lacuna aceitável: assim para Le Douaren e para Baron, que fazem referência à figura dos quase dominium nos seus comentários aos "Libri feuodrum"66.

\section{Muito pontual Le Douaren:}

Non enim dicimus dominium transferri in beneficiarium, sed tantum datur ei fundus fruendus, sicut dicitur de emphyteusi. Sed Obertus ostendit in hoc cap. usumfructum in accipientem transire

\footnotetext{
${ }^{66}$ Também sobre o problema da autoridade dos Libri feudorum Le Douaren, a respeito da intransigência de Dumoulin, tem uma posição mediana: "scio magni ponderis esse in iudiciis, etsi non ausim affirmare an habeat auctoritatem legis. Neque tamen ea res debet nos Gallos a lectione huius libri deterrere, sine quo ne mores quidem patriae recte intelligi poterunt" (LE DOUAREN, François. Commentarii in Consuetudines feudorum, cap. I, n. 5. In: DUARENI, Francisci ... Opera, Frankfurt, 1592.
} 
non tantum, sed ad ipsius etiam haeredes: ex quo intelligimus usumfructum hic non esse, qui morte finitur, sed quasi-dominium transferri in beneficiarium intelligitur, ita ut utiiis ei actio competat, sicut emphyteutae ...Obertus utitur verbo fruendi, quia aliud non habet, non quod verus sit ususfructus ${ }^{67}$.

Um pouco menos pontual, mas igualmente firme nas escolhas, Baron:

Nec quemquam moveat, quod beneficiarius possessor et fructuarius apud Ortensium dicatur, proprietate eius ad alium relata. Nam insolens non est fructuarios et possessores rerum eos appellare, qui ad haeredes suos eas transmittunt, qui tamen quasi domini sunt, res vendicant et plenissimam earum detentationem habent, non solum usumfructum, qui morte finiri solet ${ }^{68}$.

Os dois homines novi não se distanciam muito da interpretação que da definição obertina fazia o direito comum clássico; somente que, sendo inaceitável para esses a categoria "magistral" do domínio útil ${ }^{69}$, a solução está em construir uma figura muito mais próxima do dominium, que consiga exprimir em modo tecnicamente adequado a substancialidade de poderes sobre a coisa e a plenitude de ação processual da qual é titular no século XVI o feudatário.

Em Le Douaren o repetido confronto é com a enfiteuse, enquanto Baron deixa escorrer entre as mãos aquela referência a uma "pleníssima detentatio rerum" que, se é muito eficaz como imagem genérica para descrever-nos quão pesado fossem sobre os bens esses concessionários, é muito pouco rigoroso como qualificação técnico-jurídica.

${ }^{67}$ LE DOUAREN. Commentarius in Consuetudines feudorum, cit., cap. II, Quid sit feudum, n. 2.

${ }^{68}$ BARO, Eguinarius. Methodus ad Obertum Ortensium de beneficiis (in EGUINARII, Baronis. Opera omnia, Lutetiae, 1562, t. III) lib IIII, caput VII, fol. 395. Cf. também, ibidem, lib. I, cap. I, fol. 327.

${ }^{69} \mathrm{Cf}$. a documentação oferecida in: La categoria del dominio utile e gli 'homines novi'del quadrívio cinquecentesco (infra, nesse mesmo volume). 
É certo, de todo modo, que para esses o vassalo não é usufrutuário. $\mathrm{Na}$ convicção de ambos, bastaria, para afastar a ideia, apesar da ambiguidade das palavras, da referência de Oberto a uma situação que não se exaure com a morte do concessionário, mas é transmissível aos seus herdeiros. Usus-fructus, longe de designar na mente do cônsul milanês a romana servidão pessoal, é expressão linguística genérica que assinala um genérico conteúdo econômico, sem alguma intenção de coincidir com o instituto homólogo - e específico - próprio do vocabulário técnico dos juristas.

À parte, a desejada remoção do esquema do domínio útil, o velho Jacopo Belvisi, já mencionado, teria podido subscrever a conclusão dos dois Mestres franceses.

\section{O Feudo como Usufruto: as veias ideológicas da construção de Cujas}

Até aqui, mesmo na natural diversidade de abordagens derivadas dos diferentes climas históricos e das modificadas certezas metodológicas, a interpretação da definição obertina se move em um fio de continuidade que liga Belvisi a Le Douaren; uma continuidade que foi valorada por um mesmo e único observatório do qual os juristas parecem examinála, isto é, o cognoscitivo: mede-se o seu conteúdo do mesmo modo que a realidade histórica circundante; mesmo que se frequentemente não se coloca a preocupação de historicizar o texto obertino, ele é colocado sempre em confronto e em contraponto com aquilo que o instituto feudal realmente representou na efetividade social e jurídica, com aquele "real" que é o feudo na sociedade tardo-medieval e pós-medieval.

Uma brusca interrupção desse fio de continuidade se verifica, porém, com a publicação, em 1566, do comentário aos Libri de Jacques $\mathrm{Cujas}^{70}$. Procura-se entender o pensamento do jurista tolosano lendo aqueles que nos parecem os textos mais significativos.

${ }^{70}$ BERRIAT-SAINT-PRIX. Histoire de Cujas, em apêndice a Histoire du droit romain suivie de l'histoire de Cujas, Paris, Fanjat, 1821, p. 468. 
A definição obertina é trazida com fidelidade minuciosa no comentário dedicado à carta para Anselmo:

Est igitur feudum beneficium, quod perpenso animo datur, ita ut proprietas rei immobilis penes remaneat, usufructus in accipientem perpetuo jure transeat sub onere fidei et serviti certi incertive plurimumque militiae ${ }^{71}$.

Objeta-se, com razão, que para o nosso problema esse texto é muito obscuro, tanto que a vaga referência ao usufructus poderia ser suscetível de uma pluralidade de interpretações, todas legítimas, de modo que o próprio Cujas, pronto a afastar qualquer dúvida na definição de feudo que, sempre sob a esteira de Oberto, mas mais livremente, ele antepõe a todo o seu comentário, no preâmbulo geral:

Quid est feudum? Jus praedio alieno in perpetuum utendi fruendi, quod pro beneficio dominus date a lege, ut qui accipit sibi fidern et militiae múnus aliudve servitium exhibeat. Jus est, non praedium ipsum ... et jus ususfructus. Solet ususfructus constitui in personam tantum. Sed tamen conveniri potest, ut et in haeredem fructuarii transeat. Verum enim haec pactio a Justiniano coarctatur ad primum haeredem, ne in universum inutilis sit proprietas semper abscedente usufructu ... Quin imo receptum est conveniri posse, ut ad successionem transeat in infinitum, si modo addatur lex fidei, hominii, servitii, ut diximus, quae efficit ne sit inutilis proprietas ... Sic fit ut non sit inutilis proprietas, licet ususfructus in perpetuum constituatur, et pleniori quidem jure quam soleat ususfructus esse: nam et vasallus fundi ac serviturum vindicationem habet, et fructus suos facit quoquo modo terra separatos, quae non solent fructuario dari ${ }^{72}$.

Trata-se de um texto complexo, mas eloquentíssimo justamente na sua complexidade. Inicialmente, esclarece-se por completo o que pensa

\footnotetext{
${ }^{71}$ CUJACII, Jacobi. De feudis libri quinque ... aucti, emendati atque etiam explicati studio et diligentia. In: Opera, T. II, Neapoli, 1722, lib III, tit. I, De beneficio quid sit et quibus modis amittatur, col. 1264.

${ }^{72}$ De feudis, cit., lib. I, princ., col. 1181.
} 
Cujas quando transcreve de Oberto o termo ususfructus. Ele não pensa em uma coisa vaga, mas em algo tecnicamente muito preciso, isto é, à servidão pessoal de usufruto; tanto é verdade que ele se dá o que fazer para resolver o problema de uma harmonização do romanístico usufruto, que normalmente, quando é feudo próprio, é ao invés transmissível aos herdeiros também em caráter perpétuo.

A solução está em perceber que a ratio do velho princípio romano apoiava-se sobre a exigência de não tornar inutilis a propriedade por um período muito prolongado e que o princípio foi superado pela particular estrutura do contrato feudal. Isso, prevendo por parte do vassalo a continuada prestação da fidelidade, da homenagem e do serviço militar, torna injustificada a extensão do princípio, já que na relação feudal - também perpétua - a propriedade do senhor, mesmo sem conteúdo econômico para o destaque do uti-frui, não foi jamais reduzida a um vazio simulacro para a subsistência de prestações extrapatrimoniais.

A conclusão é, portanto, que a perpetuidade, no caso do feudo, não obsta em qualificá-lo corretamente como usufruto.

Até aqui, tudo se insere na coerência e na razoabilidade das soluções técnicas; mas o feudo é realidade embaraçosa demais para quem a olha com um olhar requintadamente romanístico: o vassalo tem de fato uma gama muito vasta de poderes, que o destacam muito da figura tradicional do usufrutuário, o qual - também para o tolosano - é a frágil estrutura desenhada pelos clássicos e por Justiniano e retomada depois em toda a duração do direito comum. E Cujas recorda aqui o poder de reivindicar o mesmo fundo e de fazer próprios os frutos já com a divisão, mas se deve acrescentar também aquele relevantíssimo poder de constituir sobre o fundo de direitos reais limitados, o qual o nosso jurista faz menção em outros lugares ${ }^{73}$.

Aqui o discurso do jurista se desliga sem nem menos uma tentativa de justificação técnica; prende-nos simplesmente diante da singularidade desse estranho e pouco compreensível usufruto. Todavia - e este é o ponto que urge destacar - a qualificação jurídica permanece firme,

${ }^{73}$ Cf. De feudis, cit., lib. II, tit. IX, De jure quod in feudo vasallus habet, col. 1243. 
nem se coloca a dúvida sobre a validade da própria qualificação. Cujas permanece teimosamente ligado à hipótese do usufruto em sentido estrito e a uma interpretação literal da definição obertina.

Não se pode não questionar as razões disso, sobretudo quando se constata que aquela teimosia acarreta para o jurista um grande custo sobre o plano da coerência interna do seu discurso. Cujas não pode negar uma práxis, valorada pela doutrina e jurisprudência, em que o feudatário, particularmente na França dos séculos IV ao VI, distingue-se por uma notável intensidade de poderes sobre o bem concedido; põe sobre esse personagem a veste jurídica de usufrutuário, percebendo logo que ele the é muito estreita; sente a exigência de justificar aquele revestimento, mas a justificação - como se viu - permanece no ar, inacabada, incompleta, já que não se justifica nada quando se admite somente que se trata de um usufrutuário que não tem os poderes usuais do usufrutuário.

Outros textos do comentário de Cujas aos Libri podem nos permitir entender melhor os motivos profundos de uma abordagem do tipo. O aceno a uma constituição do Imperador Lotário em tema de precariae requer que Cujas abra um discurso sobre essa figura artificial da prática notarial do alto medievo como forma unitária de contratos agrários pelo conteúdo substancial, mas muito variado ${ }^{74}$; um discurso que deliberadamente o jurista estende ao contrato de nível, à enfiteuse, ao feudo:

Precaria est cessio ususfructus rei immobilis; idem possis dicere feudum esse, idem emphyteusim, idem libellariam: nam proprietatem retinet qui dat; aut igitur nihil aut usumfructum dat et cedit. Utile dominium nullum est, ut recte sensit vulgaris interpres quisquis est, sive Pileus sive Conradus (nam hi duo sunt vetustiores horum librorum interpretes) ad tit. de alienatione feudi paterni, lib. 4. Contractuum leges sive pactiones ex quibus dicuntur contractus capere formam ita sunt dispares nonnunquam,

\footnotetext{
${ }^{74}$ Que, todavia, já na elaboração do direito comum clássico, tinha perdido (junto ao nível) as suas características originárias e originais, para tornar-se quase uma duplicata da enfiteuse (cf. GROSSI, Paolo. Le situazioni reali nell'esperienza giuridica medievale. Padova, Cedam, 1968, p. 212 ss.).
} 
ut novas appellationes excogitare sit necesse: exemplo sit pignus, aliud est pignus, aliud hypotheca, aliud fiducia, aliud ???1́????, et omnia tamen pignora. Sic aliud feudum, aliud emphyteusis, aliud libellaria, aliud precaria, aiiud ususfructus, et omnia tamen ususfructus, quoniam qui dat retinet proprietatem. Adjiciamus ergo legem precariae propriam: Precaria est cessio ususfructus rei immobilis, quae fit clerico ad tempus vel dum vixerit ea lege ut Ecclesiae ministerium exhibeat ...Quid distet precaria a feudo et libellaria si quis quaerat, consulat definitiones: nam et feudi et libellariae definitionem tradidi supra. Qui ab emphyteusi, collata etiam emphyteuseos definiti0 cum definitione precariae, statim indicabit: emphyteusis est contractus, quo dominus praedii sui usumfructum in alium transfert ea lege, ut id melius et cultius reddat constituta pensione certa. Feudo additur lex fidei et servitii, emphyteusi lex meliorationis. In aliis nulla est lex talis ${ }^{75}$.

O texto prossegue enumerando uma sucessão de peculiaridades próprias a cada contrato, mas convém interromper aqui, porque, na sequência, não acrescenta nada de relevante para o que nos interessa. Debrucemo-nos, ao invés, sobre a sugestiva sistematização que é realizada.

Se não se está errado, Cujas pretende construir - para além das diferenças trazidas pelas singulares leges contractus - uma categoria unitária: aquela dos contratos graças ao qual o dominus mantém a proprietas e transfere somente o usufruto, uma categoria cuja plataforma comum consiste essencialmente em ser todos uma cessio ususfructus; o resto vem depois. A causa de melhoramento na enfiteuse, o sinalagma proteção/fidelidade no feudo, e assim por diante, inserem-se sobre uma base que acomuna tudo o que se acaba de definir.

A esse ponto, não é peregrino questionar-se qual sentido tenha toda essa operação que reúne juntos um facho de estruturas contratuais casualmente tão diversificadas. As coisas estarão mais claras se leva-se em conta que, no auge da escola dos comentadores, os Doutores de direito comum tivessem já dado vida a uma outra categoria, aquela dos contratos

${ }^{75}$ De feudis, cit., lib. I, tit. V, Qualiter heres investitoris teneatur, col. 1208. 
translativos do domínio útil e não do direito. Como aponta um célebre e bem conhecido texto de Baldo, são seis, e são precisamente a enfiteuse, o feudo, a precária, o contrato de nível, a locação a longo prazo e o contrato de superfície ${ }^{76}$. É fácil constatar que os primeiros quatro coincidem com os contratos de que fala Cujas ${ }^{77}$.

$\mathrm{O}$ escopo do tolosano parece ser o de opor uma nova categoria à velha construída pelos Comentadores, uma nova categoria que elimine a repugnante figura do domínio útil. Ele de fato insiste sobre esse esquema técnico: a propriedade bem firme nas mãos do concedente, o qual "aut nihil aut usumfructum dat et cedit", em que é notória a tentativa de salvaguardar o primeiro e de humilhar o quanto possível o concessionário, de reduzi-lo a um personagem juridicamente bem mais frágil do que o incômodo dominus utilis. O domínio útil não existe, é o fruto de erros exegéticos e de maus diagnósticos técnicos em tema de actiones utiles; existe somente um usufruto que se destacou da plenitude do dominium. Dirá a plenos pulmões Cujas no preâmbulo geral do seu comentário:

Vasalli praedia feudalia ususfructus tantum jure perpetui ve1 tempo- rarii, proprietas est dominorum a quibus praedia acceperunt beneficii jure: usumfructum dicimus cum Oberto iib. 3 quod interpretes utile dominium vocant, propterea quod vasallus rei in feudum datae utilem non directam vindicationem habet ... quae

\footnotetext{
76 "sex dicunt esse contractus ex quibus transfertur dominium utile et non directum, sicut contractus superficiarius, contractus locationis ad longum tempus, contractus emphyteuticus, contractus qui dicitur precaria in genere foeminino, contractus livellarius et contractus feudalis" (UBALDI, Baldi perusini ... In quartum et quintum Codicis libros, Venetiis, 1577, in titulum de jure emphyteutico, n. 1 ss.).

${ }^{77} \mathrm{O}$ contrato de superfície parece menos relevante aos olhos de Cujas, porque aquilo que, sobretudo, o preocupa é a análise dos contratos de concessão fundiária. Também a locação a longo prazo é concessão fundiária, mas, enquanto locação, é por sua natureza transferência de uma certa quantidade de uti-frui no condutor; enquanto locação, é por sua natureza cessão da mera detenção no condutor e é fácil demonstrar que a locatio ad longum tempus com eficácia real é uma "aberração" de Acursianos e Bartolistas. Mais árduo é ao invés o discurso sobre o contrato feudal e enfiteutico, sobre o contrato de nível e sobre a precária, estruturas bastante atípicas em razão da sua origem profundamente consuetudinária.
} 
tamen ratio utile dominium non inducit, et verior est Conradi sententia lib. 4. tit. de alie. pat. feudi nullum esse dominium utile ${ }^{78}$.

"Usumfructum dicimus cum Oberto quod interpretes utile dominium vocant". O fulcro de todo o discurso cujaciano está aqui: uma batalha frontal contra o domínio útil e os seus defensores; é nessa batalha que se resumem as fortes perplexidades do antigo glosador no título " $d e$ alienatione paterni feudi" dos Libri sobre a legitimidade do domínio útil ${ }^{79}$ e se apega com tanta fidelidade à literalidade do texto obertino; que se revisitam como cessiones ususfructus contratos agrários que existiam há séculos, na consciência comum, esmagado o domínio, como enfiteuse; que se desenham como usufrutuários os concessionários que se prestavam muito mal a uma tal configuração, antes entre todos o enfiteuta cuja obrigação de melhoramento do fundo separava por diferenças essenciais de linhas da imagem do preceptor de um uti-frui. É-nos concedido anexar um último texto do comentário cujaciano, que parece convalidar plenamente a nossa interpretação:

Docet [il titolo IX del libro II - De jure quod in feudo vasallus habet] vasallum praedii in feudum dati utilem habere vindicationem et si possideat exceptionem tanquam rei quae in bonis suis sit ...et non tantum praedii sed etiam servitutis. Plus igitur habet quam fructuarius: nam fructuarius neque fundi neque servitutis vindicationem habet ... Idem quod superficiarius, emphyteuticarius, creditor hypothecarius: hi enim omnes fundi et servitutis fundo debitae vindicationem habent: nec tamen ideo utiles dominos dixeris recte: certe non creditorem, ergo nec ceteros. Sed an possunt servitutem imponere? Superficiarium constat posse. Ergo et emphyteuticarium et cre- ditorem et feudatarium. Sed finietur commisso feudo ... nec domino liber- tatem asserenti ulla obstabit praescriptio temporis, ne factum vasalli domino noceat ... Deteriorem feudi conditionem vasallus sine domini voluntate facere non potest ...quia proprietas ad eum non pertinet, nec enim nudum dominii nomen retinet is qui feudum concedit, sed etiam

\footnotetext{
${ }^{78}$ De feudis, cit., lib. I, princ., col. 1179.

${ }^{79} \mathrm{Na}$ Glosa, como rubrica do título "de alienatione paterni feudi" do livro segundo, afirmase de fato que "nec forte tutum est dicere quod utile dominium in vasallum transferatur".
} 
dominium, id est proprietatem. Est igitur dominus cum re, non sine re; non potest autem invito domino dominii causa deterior fieri ${ }^{80}$.

O vassalo "plus igitur habet quam fructuarius". O martelo do jurista bate e rebate sempre sobre o mesmo prego, porque está ali a fraqueza de todo o seu discurso, porque está ali o nó não dissolvido que macula de incoerência toda a argumentação. $\mathrm{O}$ texto, como todos os textos que escondem um manifesto tormento construtivo, tem um andamento dialético; o autor se interroga, se põe ele mesmo objeções, tenta alguma resposta. A inteligência lúcida de Cujas não pode conduzi-lo a negar a evidência, quando todos os mores Galliae (ao qual acena em uma parte, da qual se poupa o leitor) a conclamam: a confusão jurídica constituída sobre o bem do vassalo é conspícua; o costume tem realizado a seu favor uma pacífica expropriação do concedente. Uma tal premissa não foi desmentida, apenas recusa-se a extrair dela a dedução lógica. Ao contrário, é firme também nesse texto a absolutamente apodítica conclusão: "nec tamen ideou tiles dominos dixeris recte".

Vassalo, enfiteuta, superficiário, credor hipotecário podem constituir servidão sobre o fundo; admite-se essa regra técnica e se sabe perfeitamente que é admitido em tal modo um poder reservado ao dominus (a um dominus), todavia se remove mentalmente essa ideia repugnante e se limita a constatar com satisfação, mas sem ter vencido a latente e não expressada objeção, que aquelas servidões terminariam commisso feudo. Em suma, o texto reproduz as contorções, as quais Cujas nos habituou sobre o delicado tema dos poderes do feudatário e confirma o desconforto de um intérprete que se vê condenado à incoerência da defesa - evidentemente considerada irrenunciável - da sua absurda hipótese de fundo.

O pior ainda está por vir, e esse pior nos é oferecido pela parte final, em que se quer fixar com precisão os contornos jurídicos da figura do senhor: como o vassalo não tem a proprietas, assim o senhor não tem um nudum dominii nomen; a sua situação é "dominium, id est proprietas", “dominium rei". Verifica-se, aqui, o perfeito contraponto de

${ }^{80}$ De feudis, cit., lib. II, tit. IX, De jure quod in feudo vasallus habet, col. 1243. 
tudo que havia ensinado Dumoulin: lá o senhor, que se tornara o simples proprietário do seu direito de superioridade, mas juridicamente destacado da coisa com a qual mantém uma relação indireta e mediada, isto é, mediada pelo incômodo vassalo tornado proprietaire; aqui exatamente o contrário.

Mas Dumoulin é o fiel transcritor da experiência jurídica francesa consolidada nas coutumes, é o intérprete de uma transformação histórica que, quando ele vive, já está completa e que revolucionou completamente a relação senior/vassus. Quando, em 1790, o regime senhorial é abatido pela Assembleia Constituinte, a retomada da unicidade do domínio será feita reconhecendo no vassalo/proprietário útil a plenitude da propriedade, pois esse era o sentido de ao menos quatro séculos de história jurídica francesa, aquela história que, nos tempos de Cujas, já estava perfeitamente consolidada e a sua irrevogabilidade podia já ser lida nas coisas. Se Dumoulin lê nas coisas e transcreve fielmente nas suas páginas, Cujas - ao contrário - se recusa e continua a apregoar que a situação jurídica do vassalo é aquela do usufrutuário.

Acredita-se que se possa extrair a síntese de um discurso que está se tornando longo demais. A recepção literal em Cujas da definição obertina de feudo tem um valor não cognoscitivo, mas claramente ideológico: a construção técnica oferecida pelo tolosano não é a sua verdade - como é para o discurso franco de Dumoulin - mas sim a sua pseudo-verdade; trata-se de uma arquitetura revestida de diagnóstico objetivo, mas que é ao invés o instrumento partidário para obter um resultado posterior. A definição cujaciana é o momento relevantíssimo de uma guerra e de uma estratégia: ambas contra o domínio útil.

O domínio útil é uma estrutura que revela sob mais de um perfil a sensibilidade de Cujas: exegeticamente é sem dúvida um falseamento ou ao menos uma tentativa forçada, é, portanto, uma desnaturação e violação da mensagem dos clássicos; é o fruto mais típico da política do direito dos odiados acursianos e se identifica com o seu timbre de voz; é a negação daquela linha de tendência - da qual, sob a esteira do redescoberto patrimônio clássico, o próprio Cujas é portador - em direção 
à recuperação de uma propriedade única e simples, única e simples como o sujeito que a esse ponto já se revela.

A partir daqui a interpretação de Cujas, que é essa mesma uma batalha; é de fato não uma interpretação da realidade, mas contra a realidade. Lúdica, talvez, no sentido huizinghiano do termo, desvinculada como é dos embaraçantes mores Galliae que falam uma linguagem totalmente diferente; melhor ainda, ideológica, porque faz passar por leitura objetiva a guerra pessoal e particular do escritor contra a realidade. A figura do usufrutuário servia egregiamente aos seus fins: certamente titular de um direito real, mas proprietário somente do seu direito de usufruto $^{81}$, não dava nenhuma confusão jurídica ao concedente uma vez que seguia a coisa corpórea, ao fundo. É claro, de fato, que o nosso jurista, quando fala de usufruto, pensa somente na servidão pessoal, no usufruto formal, segundo uma linguagem ainda frequente no século XVI, e isso é demonstrado pelas repetidas insistências sobre a sua limitação à vida do investido.

Ainda que embaraçosa, forçada e de duvidoso sucesso técnico, é essa a operação do nosso jurista: remover os dominia utila e transformálos juridicamente em usufrutos. Enfiteutas, superficiários, contratantes de nível, precaristas, feudatários desenhados na fragilíssima trama jurídica do usufrutuário.

O mal era que essa teoria não encontrava reflexo na realidade, que a realidade tinha evoluído em outra direção, e o assinalavam com marcada evidência aqueles maiores poderes que Cujas era obrigado a constatar, que desmentiam fastidiosamente as suas construções, mas que mesmo assim existiam. A teoria arriscava de permanecer uma aventura intelectual sem ganchos com o real, uma exercitação livre.

\footnotetext{
${ }^{81}$ Para quem quisesse documentação adequada sobre a concepção cujaciana do usufruto, eis aqui alguns textos significativos: Ad africanum tractatus, in Opera, cit., T. I, ad. 1. Qui usumfructum, 36, de usufr., col. 1329 ss. Mas, sobretudo, col. 1332; Recitationes solemnes ad. tit. II. Lib. XLI, Digest. De adquirenda vel amittenda possessione, in Opera, cit., T. VIII, ad lib. XII, Naturaliter videtur, col. 271; In librum V. Codicis recitationes solemnes, in Opera, cit., T. IX, ad titulum X, Si secundo nupserit mulier, cui maritus usumfructum reliquit, col. 476.
} 


\section{Depois de Cujas: domínio útil, quase-domínio, usufruto}

Entre os homens novos que seguirão continuará a variedade de escolhas e de soluções, com a plena demonstração de que aquele universo cultural, a que se faz referência falando de neotéricos, é tudo menos unitário - ao invés, muito diversificado.

A redução do feudo a um dominium utile recupera adeptos convictíssimos na Alemanha, onde - de resto - a teória do domínio diviso continuava muito alinhada ${ }^{82}$. Schneidewin se voltará expressamente à interpretação dos Doutores convencido de que a relação superior/inferior típica da relação feudal encontrava a sua tradução mais congenial sobre o plano patrimonial na articulação domínio direto/domínio útil, quando esse último "directo subalternatur"83; e Wesenbeck opta pela configuração do domínio útil como direta e legítima consequência da gama de poderes nas mãos do feudatário, poderes impensáveis para o muito mais frágil usufrutuário ${ }^{84}$.

$\mathrm{Na}$ França, a terra onde Dumoulin consolidara doutrinalmente os resultados da práxis e da legislação coutumières, Charondas Le Caron não pode não admitir "que par le droict François le fied est mal defini

${ }^{82}$ Cf., nesse mesmo "Quaderno", quanto se teve ocasião de precisar in: La categoria del dominio utile e gli 'homines novi” del quadrívio cinquecentesco, p. 230.

${ }^{83}$ SCHNEIDEVVINI, Ioannis. Epitome in usus feudorum, Hanoviae, 1595, p. 21 ("quod feudum sit benévola et libera rei immobilis vel aequipollentis concessio cum utilis dominii translatione, retenta proprietate, sub fidelitate et exhibitione servitiorum honestorum") e p. 22 ("utile dominium transeat in recipientem vasallum scilicet accipiendo secundum Doctores ibi usumfructum pro utili dominio, quod scilicet dominio directo subalternatur et ita recognoscit superiorem dominium"). Schneidewin acrescenta: "et de dominio quotuplex sit, videte ordinariam doctrinam Bartoli" (ibidem), demonstrando o extraordinário peso da tradição na sua cultura de homem de transição com fortes ligações com a prática jurídica.

${ }^{84}$ VUESEMBECII, Matthaei. Tractatus de feudis (1584) ..., Wittebergae, 1616, caput I, n. 5 (em que se define o feudo como uma “concessio utilis dominii") e caput IX, n. 4 (em que se enumeram os relevantes poderes processuais e substanciais do vassalo e na qual se conclui: "est enim possessor et utilis dominus"). Matthäus Wesenbeck, flamengo de nascimento, é aqui inserido na área cultural alemã por ter lecionado por muito tempo na Alemanha. 
par le terme usufruict" 85 e que, ao contrário, o vassalo "est vray seigneur et tel se peut dire et non usufruicitier, ains proprietaire" $"$. É ao invés somente titular de um dominium utile como espécie do gênero dominium funitum $^{87}$ na interpretação mais romanística de François Hotman ${ }^{88}$, o qual, utilizando o instrumento lógico-sistemático das differentiae e das similitudines entre institutos comparativamente examinados, extrai deles a firme conclusão de que feudo e usufruto são dois esquemas técnicos essencialmente e não marginalmente diversificados ${ }^{89}$.

$\mathrm{O}$ gosto da differentia difundiu-se entre os humanistas justamente pela sua validade rigorosamente definitória e, portanto, pela sua capacidade de permitir o desenho de arquiteturas nítidas, logicamente fundadas ${ }^{90}$. Se na Alemanha o cultíssimo Konrad Rittershausen repete,

${ }^{85}$ LE CARON, Loys Charondas. Memorables observations du droit François rapporté au civil et canonic ilustrées des Arrests des Cours souveraines de France..., Paris, 1614, v. Fief p. 435.

${ }^{86}$ LE CARON, Loys Charondas. Pandects ou Digestes du droict François 1. II, Paris, 1607 , chap. XIX, p. 188. Os vassalos são qualificados como "seigneurs utiles proprietaires" por COQUILLE, Guy. Institution au droit des françois, in Les ouevres de maistre Guy Coquille ..., t. II, Paris, 1665, des fiefs, p. 32.

${ }^{87}$ Sobre essa construção de Hotman de uma divisão do dominium em dois, gêneros, finitum e infinitum, e da recompreensão no primeiro do domínio útil, remete-se ao que se observa em: La categoria del dominio utile e gli "homines novi" del quadrivio cinquecentesco, cit., p. 240.

${ }^{88}$ HOTMAN, François. Disputatio de feudis (1573), in Operum tomus secundus, pars altera, Lugduni, 1599, cap. XXX, de reali feudorum iure.

${ }^{89}$ HOTMAN, François. Disputatio de feudis, cit., cap. XXXI, Quibus rebus feudum est ususfructus inter se vel conveniant vel dissideant, em que estão assinaladas pontualmente as analogias e as diferenças; entre as diferenças, entre as muitas elencadas, três, sobretudo, valem para fazer do feudo e do usufruto dois esquemas técnicos substancialmente diversos: "ususfructus nullum plane dominii genus, quantum ad substantiam attinet, in fructuarium transfert ... feudum vero utile praedii dominium transfert ...; ... ususfructus necessário temporalis est, ne proprietas mortua et inutilis maneat ... feudum autem vassallus perpetuo iure sibi est, ne proprietas mortus et inutilis maneat ... feudum autem vassallus perpetuo ure sibi suisque posteris possidet; ... fructuarius proprietatis nomine legare non potest, quia neque dominus est, et si conveniatur, laudare dominum cogitur, feudatarius praedii feudalis nomine solus et agere et conveniri potest".

${ }^{90}$ Ver MORTARI, Piano V. Dialettica e giurisprudenza. Studio sui trattati di dialettica legale del sec. XVI (1957), agora in MORTARI, V. Piano. Diritto logica método nel secolo 
no início do século XVII, nas suas Partitiones iuris feudalis, a teoria do quase-domínio ensinando que o vassalo "habet [...] quasi dominium quoddam", pode fazê-lo depois de ter demonstrado per tabulas, analiticamente, as muitas e substanciais diferenças entre as duas estruturas jurídicas $^{92}$; cheio de perplexidades e de repugnâncias pela categoria do domínio úti1 ${ }^{93}$, prefere valer-se de uma classificação ambígua, mas capaz de exprimir bem a preponderância econômica e jurídica do concessionário.

Continua também a tese "obertina" do feudo como usufruto: um usufruto singularíssimo e impróprio, seja por conta daquela prestação de fidelidade que polui e deforma a relação puramente patrimonial ${ }^{94}$, seja porque se trata de um "ius utendi fruendi in perpetuum" em que o caráter da perpetuidade se afasta com um rasgo profundo do usufruto normal ${ }^{95}$.

Van Giffen, que estudou profundamente a filologia e o direito nas Universidades francesas e que reconhece Cujas entre os seus mestres, defende formalmente a tese do usufruto, mas, consciente das muitas objeções que uma solução técnica similar provoca ${ }^{96}$, viu-se forçado a

XVI. Napoli: Jovene, 1978, sobretudo, p. 147 ss.

${ }^{91}$ RITTERSHUSII, Conradi ... Partitiones iuris feudalis ..., Hanoviae, 1603, p. 314.

${ }^{92}$ Cf. Ibidem, p. 82-83 o exame analítico e detalhadíssimo das differentiae.

${ }^{93}$ Também sobre esse ponto se remete a quanto já foi por nós observado em: GROSSI, Paolo. La categoria del dominio utile e gli "homines novi" del quadrívio cinquecentesco, cit., p. 226.

94 "Feudum, a fide dictum, est ususfructus quidam rei immobilis sub conditione fidei" (VULTEJI, Hermanni ... Exegesis summa juris quod est de feudis ..., Marpurgi, 1595, p. 7. 95 "Feudum est concessio beneficiaria, per quam ius utendi fruendi in perpe- tuum re immobili transfertur in accipientem, proprietate apud dantem remanente, sub fidelitate et exhibitione servitiorum honestorum ...Ius utendi fruendi in perpetuum: in hoc differt feudum ab usufructu, quod ususfructus, quatenus est servitus personalis, ultra personam fructuarii non extenditur, feudum autem est ius utendi fruendi, quod ad vasallum et heredes eius in perpetuum pertinet". BRONCHORST, Everardo. Methodus feudorum. Lugduni Batavorum, 1613, p. 9.

96 Vê-se o significativo texto em GIPHANI, Huberti. Antinomiae iuris feudalis ... Fracofurti, 1606, p. 9 (para a definição do feudo como usufruto, um usufruto todavia perpétuo, por cuja característica "differt feudum a fructu et usu simplici, qui morte fructuarii finitur”) e p. $11 \mathrm{~s}$. (mas, sobretudo, p. 13 com a quarta objeção) para as várias objeções que o próprio jurista se coloca. 
criar ao lado da normal servidão pessoal - que é servitus simplex atque particulares e que, como tal, "est accessorium quoddam praediorum et sequitur causam vel naturam principais" - uma "quaedam servitus universalis", de fato "singularis" porque "pinguiorem, pleniorem, crassiorem et propemodum propriam naturam servituitis habet" 97 , em que a repetida, insistente adjetivação, justamente no seu caráter hiperbólico, demonstra a má consciência do jurista ao fixar uma definição formal e desmenti-la nos conteúdos ${ }^{98}$.

Há, além do mais, entre os alunos de Cujas, quem ao invés defenda a espada trazida e a tese do mestre conscientemente, partindo obviamente das suas mesmas premissas; é o alemão Johann Borcholten:

[...] vasallus igitur proprietarius non est, sed usufructuarius, non habet dominium rei infeudatae, sed duntaxat usumfructum. Et quamvis interpretes communiter contra Obertum insurgunt ac volunt vasallum non usumfructum habere, sed utile dominium ..., tamen verior est sententia Oberti vasallum usufructuarium esse ${ }^{99}$.

A dignidade primeira, que serve como fundamento e justificação, reside na esteira do tolosano, na inexistência do domínio útil: "nec enim est dominium aliquod, quod utile dicatur"100. Essa criatura artificial, desconhecida à lex e ao ius, existe somente na fantasia dos intérpretes, que quiseram com essa sua invenção conciliar os textos dos Libri feudorum que qualificavam dominus o feudatário com o princípio romano de que não podem ser corretamente hipotetizados dois domínios solidários sobre a mesma coisa. A fantasia dos intérpretes criou, do nada, dois domínios, o

\footnotetext{
${ }^{97}$ Ibidem, p. 13, nn. 45-48.

98 Talvez um repensamento, depois de tantas atormentadas reflexões, pode ser percebida no prefácio que Van Giffen escreve, um ano antes da morte, em 1603, para as já por nós citadas Partitiones iuris feudalis de Konrad Rittershausen e na qual confessa: "agis de iure in rem, quod feudum vocant, non absimile emphyteusi; certe et similius quam iuri ususfructus, extinguuntur, sed etiam ad heredes vel agnatos pertinent" (Praefatio, circa finem).

99 BORCHOLTEN, Johanne. Commentaria in consuetudines feudorum. Helmstadii, 1591, cap. I, n. 13.

${ }^{100}$ Ibidem, n. 14.
} 
direto e o útil, de qualidade diversa, mas a teoria é e permanece fantasiosa, "magno errore introducta", como demonstrou irrefutavelmente Cujas ${ }^{101}$.

\section{Referências}

ALVAROTTI, Iacobi. Lectura in iusus. Francofurti ad Moenum, 1570. Prooemium, n. 18.

BARO, Eguinarius. Methodus ad Obertum Ortensium de beneficiis. In: EGUINARII, Baronis. Opera omnia. Lutetiae, 1562. T. III, lib IIII, caput VII, fol. 395.

BELVISO, Iacobi de. Apparatus ... super consuetudinibus usus feudorum. In: BELVISO, Iacobi de. Commentarii in Authenticum et Consuetudines feudorum, Bolonha, Forni, 1971.

BLANCHO, Ioanne. Epitome feudorum (in Tractatus illustrium iurisconsultorum, cit., T. X, Pars I, fol. 263 recto.

COQUILLE, Guy. Institution au droit des françois, in Les ouevres de maistre Guy Coquille. T. II, Paris, 1665. des fiefs, p. 32.

CUJACII, Jacobi. De feudis libri quinque ... aucti, emendati atque etiam explicati studio et diligentia. In: Opera, T. II, Neapoli, 1722, lib III, tit. I, De beneficio quid sit et quibus modis amittatur. col. 1264.

${ }^{101}$ Ibidem, n. 15: “cum Titius praedium suum Sempronio concedit ea lege, ut fidem sibi praestet et servitia exhibeat, Titius dominium praedii retinet et Sempronius duntaxat usumfructum consequitur et proprio nomine feudatarius appella- tus et competit Titio actio ditecta, Sempronio utilis. Dicitur tamen Sempronius feuda- tarius quando que dominus sed abusive et improprie, quia vero unius eiusdemque rei duo in solidum domini esse non possunt [...] Ob id interpretes duplex dominium constituerunt [...] sed quia sine lege nihil loqui debemus, cum nusquam inveniatur cautum in iure, cum id non inveniatur a iure concessum, cum id non sit expressum in iute [...] et qui sine lege loquuntur, nimis alte volant sine pennis et ideo non mirum si veluti Icarus cadent [...] nos cum Obetto de Orto dicemus vasallum in feudo usumfructum habere". É instrutiva também a cartadedicatória que Borcholten coloca no início dos Commentaria, revela quanto de desprezo declarado pelos Libri feudorum e pelo direito feudal, do qual o culto jurista se ocupa somente pela grande relevância prática. 
DUMOULIN, Charles. In duos priores títulos Consuetudinis Parisiensis Commentarii. In: MOLINAEI, Caroli. Opera quae extant omnia. Parisiis, 1658. T. I, Col. 40, n. 100.

GROSSI, Paolo. 'Dominia'e 'servitutes' - Invenzioni sistematiche del diritto comune in tema di servitù. In: GROSSI, Paolo. Quaderni fiorentini per la storia del pensiero giuridico moderno, 18, 1989. GROSSI, Paolo. La proprietà e le proprietà nell'officina dello storico. In: GROSSI, Paolo Quaderni fiorentini per la storia del pensiero giuridico moderno, 17, 1988.

HOSTIENSIS, Henrici de Segusio Cardinalis. Summa aurea. Venetiis: 1574. lib. III, de feudis, n. 1

HOSTIENSIS, Henrici. In tertium Decretalium librum commentaria. Torino, Bottega d'Erasmo, 1965 (reimpressão anastástica, ed. Venetiis, 1581). De feudis, Rubrica, n. 5).

HOTMAN, François. Disputatio de feudis (1573). In: Operum Tomus Secundus, pars altera, Lugduni, 1599. Cap. XXX.

HUGOLINI [na realidade COLOMBI, Jacopo]. Summa super usibus feudorum. In: PALMERIO, J. B (Org.). B.I.M.AE., v. II. Bononiae: Virano, 1892.

ISERNIENSIS, ANDREAE. In usus feudorum comentaria. Neapoli: 1571, de capitolis Corradi, v. Praeterea, Additio, n. 9.

KELLEY, D. R. De origine feudorum: The Beginnings of an historical Problem. 1964.

KELLEY, D. R. History, Law and the Human Sciences - Medieval and Renaissance Perspectives. London, Variorum Reprints, 1984 LASPEYRES, E. A. Über die Entstehung und älteste Bearbeitung der Libri Feudorum: Aalen, Scientia, 1969 (reimpressão anastática Ausg. Berlim, 1830. p. 81-82.

LE CARON, Loys Charondas. Memorables observations du droit François rapporté au civil et canonic ilustrées des Arrests des Cours souveraines de France, Paris, 1614. v. Fief p. 435. 
LE CARON, Loys Charondas. Pandects ou Digestes du droict François 1. II, Paris, 1607. chap. XIX, p. 188.

LE DOUAREN, François. Commentarii in Consuetudines feudorum, cap. I, n. 5. In: DUARENI, Francisci. Opera. Frankfurt, 1592.

MEIJERS, E. M. L'université d'Orléans au XIII siécle, agora em Etudes d'histoire du droit. T. III, Le droit romain au Moyen Age, P. I, Leyde, Univ. Pers Leiden, 1959. p. 104-106.

MORTARI, Piano V. Dialettica e giurisprudenza. Studio sui trattati di dialettica legale del sec. XVI (1957).

MORTARI, V. Piano. Diritto logica método nel secolo XVI. Napoli: Jovene, 1978. p. 147 ss.

RAYNAUDI, Ioannis. Comprehensorium feudale. Lugduni, 1561. n. 7 e 8 .

RITTERSHUSII, Conradi. Partitiones iuris feudalis. Hanoviae, 1603. p. 314.

ROSENTALL, Henrico A. Tractatus et synopsis totius iuris feudalis. Colonia: 1610 (a primeira redação parece ser de 1588).

SCHNEIDEVVINI, Ioannis. Epitome in usus feudorum. Hanoviae, 1595. p. 21.

SEYSSELI, Claudi. Speculum feudorum. Basileae, 1566. p. 65 e 6869.

THIREAU, J. L. Charles Du Moulin (1500-1566) - Étude sur les sources, la méthode, les idées politiques et économiques d'un juriste de la Renaissance. Genève: Droz, 1980. p. 31.

ZASII, Udalrici. In usus feudorum epitome. In: ZASII, Udalrici.

Operum tomus tertius. Lugduni, 1550. Col. 268, n. 24. 
Paolo Grossi é Professor Emérito de História do Direito Medieval e Moderno na Universidade de Florença, Itália. Recebeu o título doutor honoris causa em Direito pelas Universidades de Frankfurt am Main (1989), Stockholm (1990), Autónoma de Barcelona (1991), Autónoma de Madrid (1994), Sevilla (1998), Bologna (2005), Nápoles (2007), Universidade Federal do Rio Grande do Sul (2009) e Universidade Federal do Paraná (2011). É Professor honorário na Facultad de Derecho de la Pontificia Universidad Católica del Peru. É membro da Accademia Nazionale dei Lincei. Em 1972 fundou a revista Quaderni fiorentini per la storia del pensiero giuridico moderno e o Centro Studi sulla storia del pensiero giuridico, do qual a revista é expressão. A sua produção é marcada pela influência de nomes como Santi Romano, Giuseppe Capograssi, Francesco Calasso e Marc Bloch. Em 2009 foi nomeado Ministro da Corte Constitucional da República Italiana através de decreto assinado pelo Presidente da República Italiana, Giorgio Napolitano, e de fevereiro de 2016 a fevereiro de 2018 exerceu a Presidência da Corte.

E-mail: urp@unifi.it.

Endereço profissional: S. Marco, 4 - 50121, Firenze, Itália. 